\title{
Kajian Penambahan Dosis Beberapa Pupuk Hijau dan Pengaruhnya Terhadap Pertumbuhan Tanaman Selada (Lactuca sativa L.)
}

\author{
Yuni Agung Nugroho ${ }^{1}$, Yogi Sugito ${ }^{2}$, Lily Agustina ${ }^{2}$ Soemarno $^{2^{*}}$ \\ ${ }^{1}$ Program pascasarjana, Universitas Brawijaya, Malang \\ ${ }^{2}$ Fakultas Pertanian, Universitas Brawijaya, Malang
}

\begin{abstract}
Abstrak
Penambahan pupuk hijau pada budidaya selada anorganik bertujuan mendapatkan dosis beberapa pupuk hijau yang dapat meningkatkan pertumbuhan selada dan meningkatkan kesuburan tanah. Penelitian menggunakan Rancangan Acak Kelompok diulang tiga kali. Pemberian pupuk urea dengan dosis $100 \mathrm{~kg} \cdot \mathrm{ha}^{-1}$ sebagai kontrol. Perlakuan penambahan pupuk hijau adalah penambahan Tithonia 5 ton.ha ${ }^{-1}\left(\mathrm{OT}_{1}\right), 10$ ton.ha ${ }^{-1}\left(\mathrm{OT}_{2}\right)$, Tithonia 15 ton.ha ${ }^{-1}\left(\mathrm{OT}_{3}\right)$; penambahan Gliricidia 5 ton.ha ${ }^{-1}\left(\mathrm{OG}_{1}\right), 10$ ton.ha ${ }^{-1}\left(\mathrm{OG}_{2}\right), 15$ ton.ha- ${ }^{-1}\left(\mathrm{OG}_{3}\right)$; penambahan Cromolaena 5 ton.ha ${ }^{-1}\left(\mathrm{OC}_{1}\right)$, 10 ton.ha ${ }^{-1}\left(\mathrm{OC}_{2}\right)$, dan 15 ton.ha ${ }^{-1}\left(\mathrm{OC}_{3}\right)$. Pengamatan tanaman selada meliputi Bobot Segar Tanaman, Bobot Kering Tanaman, Indeks Luas Daun, Laju Pertumbuhan Tanaman, dan Laju Asimilasi Bersih. Pengamatan tanah meliputi C organik tanah, $\mathrm{N}$ total, $\mathrm{KTK}, \mathrm{pH}$, Bobot Isi Tanah dan $\mathrm{CN}$ rasio. Analisa ragam dilakukan terhadap peubah pengamatan tanaman selada dan kesuburan tanah, uji Tukey dan uji kontras dilakukan bila ada pengaruh nyata perlakuan terhadap peubah pengamatan. Uji regresi linier berganda dilakukan terhadap sekumpulan peubah kesuburan tanah terhadap hasil tanaman selada. Hasil menunjukkan bahwa penambahan Tithonia, Gliricidia dan Cromolaena sebesar 5 ton.ha ${ }^{-1}$ pada tanaman selada yang dipupuk urea meningkatkan indeks luas daun, bobot segar dan kering tanaman, dan laju pertumbuhan tanaman. Bobot segar tanaman selada tertinggi sebesar 17,18 ton. ha $^{-1}$ dicapai pada penambahan Tithonia 15 ton.ha ${ }^{-1}$ yang berarti meningkat $88 \%$ dari pemupukan urea. Penambahan pupuk hijau Tithonia, Gliricidia dan Cromolaena sebesar 5 ton.ha ${ }^{-1}$ pada budidaya selada meningkatkan KTK dan C organik tanah setelah panen. Residu C organik tanah tertinggi 2,97\% meningkat 53,1\% dan KTK tanah tertinggi 43,24 me.100 $\mathrm{g}^{-1}$ meningkat 14,75\% dari kontrol oleh penambahan Cromolaena 15 ton. ha ${ }^{-1}$. KTK tanah, $\mathrm{N}$ total, Bobot Isi tanah, dan pH tanah berturut-turut mempunyai pengaruh positif dan nyata terhadap bobot segar tanaman saat panen.
\end{abstract}

Kata kunci: Pupuk hijau, pupuk buatan, tanaman selada.

Abstract

Addition of green fertilizer for lettuce anorganic cultivation was aimed to determine the doses of several green fertilizers which can increase the growth of lettuce and soil fertility. We used Group Randomized Design with 3 replications. Urea fertilizer of $100 \mathrm{~kg} \cdot \mathrm{ha}^{-1}$ dose as kontrol. The addition of green fertilizer are: Tithonia 5 ton.ha ${ }^{-1}\left(\mathrm{OT}_{1}\right)$, 10 ton.ha ${ }^{-1}\left(\mathrm{OT}_{2}\right)$, Tithonia 15 ton.ha ${ }^{-1}\left(\mathrm{OT}_{3}\right)$; Gliricidia 5 ton.ha ${ }^{-1}\left(\mathrm{OG}_{1}\right), 10$ ton.ha ${ }^{-1}\left(\mathrm{OG}_{2}\right), 15$ ton.ha ${ }^{-1}\left(\mathrm{OG}_{3}\right)$; Cromolaena 5 ton.ha ${ }^{-1}\left(\mathrm{OC}_{1}\right), 10$ ton.ha ${ }^{-1}\left(\mathrm{OC}_{2}\right)$, and 15 ton.ha ${ }^{-1}\left(\mathrm{OC}_{3}\right)$. Growth of lettuce were observed, include: fresh and dry weight, Index of leaf area, growth rate, and Net Assimilation Rate. Soil parameters include: C organic, $\mathrm{N}$ total, $\mathrm{CEC}, \mathrm{pH}$, bulk density and $\mathrm{CN}$ ratio. ANOVA was conducted on the variable of lettuce's growth and soil fertility, Tukey and Contrast Test applied if the treatment give significant effect on the observed parameter. Multiple linear regression was applied on the variable of soil fertility towards the growth of lettuce. Results showed the addition of Tithonia, Gliricidia and Cromolaena for 5 ton.ha ${ }^{-1}$ on anorganic lettuce increase the leaf area index, fresh and dry weight, and growth rate. Highest fresh weight is 17.18 ton.ha ${ }^{-1}$ on the addition of 15 ton.ha ${ }^{-1}$ Tithonia which implied $88 \%$ increasing from control. The addition of Tithonia, Gliricidia and Cromolaena for 5 ton.ha ${ }^{-1}$ on lettuce cultivation increases CEC and C organic of soil after harvest. Highest residue of C organic for $2.97 \%$ means increasing of 53,1\% and highest CEC for $43.24{\text { me. } 100 \mathrm{~g}^{-1}}^{-1}$ which increased $14.75 \%$ compare to control, obtained from the treatment of Cromolaena 15 ton.ha ${ }^{-1}$. Soil's CEC, N total, bulk density, and $\mathrm{pH}$ have positive and significant effect on fresh weight at harvest time, respectively.

Keywords: artificial fertilizer, green fertilizer, lettuce.

\section{PENDAHULUAN}

Selada merupakan tanaman introduksi yang sudah beradaptasi di Indonesia, dan mempunyai

\footnotetext{
* Alamat Korespondensi:

Soemarno

Email : smno@ub.ac.id

Alamat : Program Pascasarjana, Universitas Brawijaya, Jl. Mayjen Haryono No. 169 Malang 65145
}

prospek ekonomi cukup tinggi. Prospek cerah tersebut ditunjukkan oleh beberapa hal, yaitu harga selada yang relatif tinggi, pasar yang cukup luas dan manfaat selada bagi manusia karena mengandung vitamin $\mathrm{A}, \mathrm{B} 1$, dan $\mathrm{C}$.

Pembudidayaan selada dilakukan petani dengan penerapan teknologi sarat bahan kimia, utamanya adalah pemanfaatan pupuk anorganik. Pemakaian pupuk anorganik secara terus- 
menerus pada lahan pertanian tanpa diimbangi pemberian bahan organik yang memadai ke dalam tanah, berdampak pada penurunan produktifitas tanah, dikarenakan menurunnya kesuburan tanah secara menyeluruh, yaitu kesuburan kimia, fisik dan biologi. Perkembangan konsumsi pupuk kimiawi di Indonesia terus meningkat sejak tahun 1975 hingga sekarang. Selama kurun waktu 20 tahun terakhir, terjadi kenaikan penggunaan pupuk kimiawi hampir 5 kali lipat, sementara produksi pertanian untuk tanaman pangan dimana pupuk tersebut digunakan hanya meningkat 50 persen. Hal ini menunjukkan bahwa penggunaan pupuk anorganik sudah tidak efisien dan bahkan terjadi penurunan produktifitas lahan karena menurunnya kandungan bahan organik tanah [1].

Sistem pertanian modern menuntut adanya penggunaan lahan secara intensif tanpa memperhatikan masukan bahan organik, sehingga ketersediaaan bahan organik tanah cepat mengalami penurunan maka degradasi penurunan kesuburan tanah banyak terjadi. Kandungan bahan organik di sebagian besar lahan di Jawa berada di bawah $2 \%$, padahal tanah subur mensyaratkan kandungan bahan organik tanah berkisar dari 2,5\% sampai dengan $4 \%$.

Bahan organik merupakan penyangga biologi yang mempunyai fungsi dalam memperbaiki sifat-sifat fisik, kimia dan biologi tanah, sehingga tanah dapat menyediakan unsur hara dalam jumlah berimbang. Terdapat korelasi positif antara kadar bahan organik dengan produktifitas tanah. Bahan organik juga berfungsi sebagai sumber bahan energi bagi mikrobia $[2,3]$. Di daerah produsen selada yang ketersediaan pupuk kandangnya terbatas, menjadi pembatas dalam pemberian bahan organik, sehingga perlu dilakukan penambahan bahan organik dalam bentuk lain yang didukung oleh potensi bahan organik tersebut di daerah. Pemanfaatan sisa tanaman potensial asli daerah sebagai pupuk hijau merupakan salah satu alternatif untuk mensuplai bahan organik tanah. Kecepatan pelapukan suatu jenis bahan organik ditentukan oleh kualitas bahan organik tersebut. Kualitas bahan organik berkaitan dengan kecepatan penyediaan dan besarnya unsur hara $N$, ditentukan oleh besarnya kandungan $\mathrm{N}$, lignin, dan polifenol. Bahan organik dikatakan berkualitas tinggi apabila mempunyai $\mathrm{N}>2,5 \%$, lignin < $15 \%$, dan polifenol < 4\% [4].

\section{METODE PENELITIAN}

Penelitian disusun menggunakan Rancangan Acak Kelompok dimana terdapat sepuluh perlakuan, masing-masing perlakuan diulang tiga kali (Tabel 1). Penelitian dilakukan di lapang dimana penyemaian benih dilakukan pada bedengan dengan menambahkan pupuk kandang pada tanah. Pemindahan tanaman dilakukan pada saat bibit berumur 3 minggu setelah sebar. Pemindahan bibit ke bedengan dilakukan setelah bibit berumur 3 minggu. Bibit yang ditanam dipilihkan yang seragam. Setiap lubang tanam, ditanami satu bibit dengan jarak tanam $25 \mathrm{~cm} \times 25 \mathrm{~cm}$. Pupuk urea diberikan untuk semua perlakuan pada saat tanaman berumur $1 \mathrm{MSPT}$, dengan dosis Urea 100 kg.ha ${ }^{-1}$. Pupuk organik (pupuk hijau) diberikan dalam bentuk segar yang dipotong-potong dengan ukuran $2 \mathrm{~cm}$, pada saat dua minggu sebelum tanam dengan dosis sesuai perlakuan.

Tabel . Rancangan penelitian

\begin{tabular}{clcr}
\multicolumn{4}{c}{ Tabel . Rancangan penelitian } \\
\cline { 2 - 4 } Kelompok & \multicolumn{3}{c}{ Perlakuan } \\
\cline { 2 - 4 } & Jenis Pupuk & $\begin{array}{c}\text { Pupuk hijau } \\
\text { ton.ha }\end{array}$ & $\begin{array}{c}\text { N } \\
\text { kg.ha }\end{array}$ \\
\hline An & Urea & - & 46,000 \\
$\mathrm{OT}_{1}$ & T.diversifolia & 5 & 82,494 \\
$\mathrm{OT}_{2}$ & T.diversifolia & 10 & 118,988 \\
$\mathrm{OT}_{3}$ & T.diversifolia & 15 & 155,482 \\
$\mathrm{OG}_{1}$ & G. sepium & 5 & 85,160 \\
$\mathrm{OG}_{2}$ & G.sepium & 10 & 123,952 \\
$\mathrm{OG}_{3}$ & G.sepium & 15 & 162,928 \\
$\mathrm{OC}_{1}$ & C. odorata & 5 & 76,970 \\
$\mathrm{OC}_{2}$ & C.odorata & 10 & 107,940 \\
$\mathrm{OC}_{3}$ & C.odorata & 15 & 161,910 \\
\hline
\end{tabular}

Pemeliharaan tanaman dilakukan dengan menggunakan pestisida organik apabila tanaman menunjukkan gejala serangan organisme pengganggu tanaman. Gulma dikendalikan secara mekanis. Pengairan diberikan apabila tanah sudah berkurang kelembabannya, sehingga tanah selalu dalam keadaan lembab.

Pengamatan penelitian dilakukan terhadap tanaman secara non destruktif dan destruktif. Pengamatan terhadap tanaman secara non distruktif dilakukan 1 minggu setelah tanam dengan interval satu minggu sekali, terhadap peubah sebagai berikut : Bobot segar tanaman pada saat panen, dengan satuan gram. Bobot kering tanaman pada saat panen, dengan satuan gram. Luas daun pada saat panen, diukur dengan leaf area meter, satuan $\mathrm{cm}^{2}$.

Pengamatan destruktif dilakukan terhadap peubah sebagai berikut : Luas daun diukur dengan leaf area meter, satuan $\mathrm{cm}^{2}$. Penga- 
matan dilakuan pada saat tanaman berumur 2 dan 3 minggu setelah pindah tanam, dengan satuan $\mathrm{cm} 2$. Bobot segar tanaman, pengamatan dilakukan pada umur 2 dan 3 minggu setelah pindah tanam, dengan satuan gram (g). Bobot kering tanaman, pengamatan dilakukan pada umur 2 dan 3 minggu setelah pindah tanam, dengan satuan gram (g).

Pengamatan terhadap media tanam (tanah) dilakukan dalam tiga kategori, yaitu pada saat sebelum penanaman, pada saat tanaman berumur 2 minggu setelah pindah tanam, dan pada saat setelah panen.

Pengamatan sebelum tanam meliputi: Kandungan Nitrogen, kandungan bahan organik tanah, kapasitas Tukar kation. Adapun variabel tanah yang diamati pada saat tanaman berumur 3 minggu setelah pindah tanam adalah Kandungan Nitrogen meliputi $\left(\mathrm{NO}_{3}{ }^{-}, \mathrm{NH}_{4}\right.$ dan $\mathrm{N}$ total), KTK, PH dan variabel tanah yang diamati pada saat setelah panen adalah kandungan bahan organik tanah, $\mathrm{N}$ total, dan KTK.

\section{Analisis data}

Analisa ragam dilakukan terhadap peubah berat segar tanaman, berat kering, luas daun, laju pertumbuhan tanaman dan laju asimilasi bersih, pada nilai $\alpha=5 \%$. Apabila perlakuan memberikan pengaruh yang nyata terhadap peubah pengamatan, maka dilakukan uji pembanding, dengan Uji Beda Nyata Jujur. Pembandingan antara kontrol dengan perlakuan dilakukan secara ortogonal kontras, untuk mengetahui pengaruh penambahan pupuk hijau terhadap pertumbuhan selada.

\section{Analisis Pertumbuhan Tanaman Indek Luas Daun}

Indek Luas Daun adalah perbandingan luas daun total dengan luas tanah yang ditutupi. Persamaan indek luas daun adalah :

$$
\text { ILD = LD : LT }
$$

Keterangan :

ILD = Indek Luas daun

LD = Luas Daun pada saat pengamatan

LT = Luasan Tanah dari jarak tanam selada

\section{Laju Asimilasi Bersih}

Laju Asimilasi Bersih $(\mathrm{LAB})=$ Net assimilation rate (NAR) adalah parameter pertumbuhan yang menunjukkan kemampuan daun dalam menghasilkan bahan kering total tanaman per satuan luas daun yang dihasilkan per satuan waktu.
Rumus yang dinyatakan oleh Hunt [5] sebagai berikut :

$$
L A B=\frac{W_{2}-W_{1}}{T_{2}-T_{1}} \cdot \frac{\ln L D_{2}-\ln L D_{1}}{L_{2}-L D_{1}}
$$

Keterangan :

$\mathrm{W}_{1}=$ Bobot kering tanaman saat pengamatan satu

$\mathrm{W}_{2}=$ Bobot kering tanaman saat pengamatan dua

$\mathrm{T}_{1}=$ Umur tanaman pada saat pengamatan satu

$\mathrm{T}_{2}=$ Umur tanaman pada saat pengamatan dua

$\mathrm{LD}_{1}=$ Luas daun pada pengamatan satu

$\mathrm{LD}_{2}=$ Luas daun pada pengamatan dua

\section{Crop Growth Rate}

Laju Pertumbuhan tanaman atau Crop Growth Rate (CGR) menurut Hunt [5] dapat dinyatakan sebagai nilai rata-rata pertumbuhan tanaman yang dihitung tanpa mendasarkan nilai laju asimilasi bersih dan indek luas daun, dengan persamaan sebagai berikut:

$$
\text { LPT }=\frac{1}{\operatorname{LT}\left(\mathrm{T}_{2}-\mathrm{T}_{1}\right)}
$$

Keterangan :

$\mathrm{W}_{1}=$ Berat Segar tanaman saat pengamatan satu

$\mathrm{W}_{2}=$ Berat Segar tanaman saat pengamatan dua

$\mathrm{LT}=$ Luas Tanah

$\mathrm{T}_{1}=$ Umur tanaman pada saat pengamatan satu

$\mathrm{T}_{2}=$ Umur tanaman pada saat pengamatan dua

\section{HASIL DAN PEMBAHASAN}

\section{Pertumbuhan Tanaman Selada}

Perlakuan memberikan pengaruh nyata terhadap: indek luas daun selada pada umur 3 MSPT, 4 MSPT dan 5 MSPT. Terhadap bobot segar dan kering total tanaman selada pada semua umur pengamatan. Pembandingan ortogonal kontras menunjukkan penambahan 5 ton.ha ${ }^{-1}$ pupuk hijau mampu meningkatkan secara nyata terhadap indek luas daun pada umur 3 MSPT, 4 MSPT dan 5 MSPT, bobot segar dan bobot kering tanaman pada umur 2 MSPT, 3 MSPT, 4 MSPT, dan 5 MSPT.

Perlakuan $\mathrm{OT}_{3}$ menghasilkan nilai tertinggi terhadap indeks luas daun umur 3, 4, dan 5 MSPT. Rata-rata ILD pada saat panen ditunjukkan pada Gambar 1.

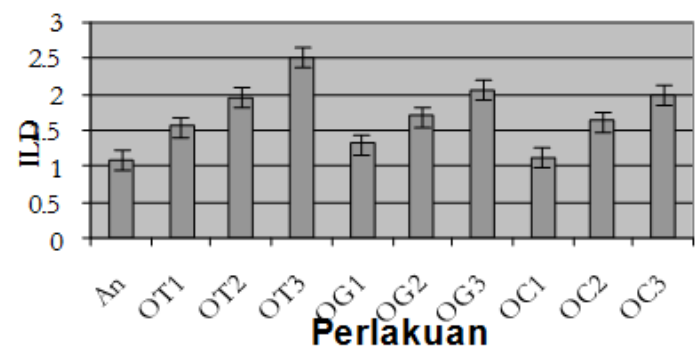

Gambar 1. Rata-rata ILD pada saat panen 
Penambahan 5 ton.ha ${ }^{-1}$ pupuk hijau dapat meningkatkan indek luas daun pada saat panen sebesar 0,239. Hasil analisa regresi menunjukkan adanya hubungan antara indek luas daun selada dengan dosis pupuk hijau pada saat panen. Tithonia menunjukkan pengaruh lebih tinggi untuk setiap dosis yang diujikan dibanding dengan pupuk hijau lainnya. Hubungan ILD dengan dosis pupuk hijau ditunjukkan pada Gambar 2.

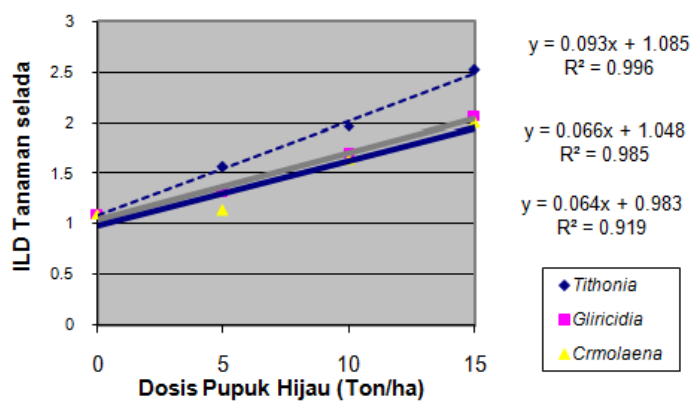

Gambar 2. Hubungan ILD dengan dosis pupuk hijau

Nilai bobot segar tertinggi pada umur 3 dan 5 MSPT diberikan oleh $\mathrm{OT}_{3}$, sedangkan pada umur $4 \mathrm{MSPT}$, perlakuan $\mathrm{OT}_{3}$ tidak berbeda nyata dengan perlakuan $\mathrm{OT}_{2}$, OG3, dan $\mathrm{OC}_{3}$. Hasil analisa regresi menunjukkan adanya hubungan antara bobot segar selada dengan dosis pupuk hijau pada saat panen. Peningkatan dosis pupuk hijau yang diberikan masih memberikan peningkatan bobot segar tanaman selada, dosis 15 ton.ha ${ }^{-1}$ memberikan bobot segar tertinggi diantara dosis yang diujikan. Hubungan bobot segar tanaman selada dengan dosis pupuk hijau ditunjukkan pada Gambar 3.

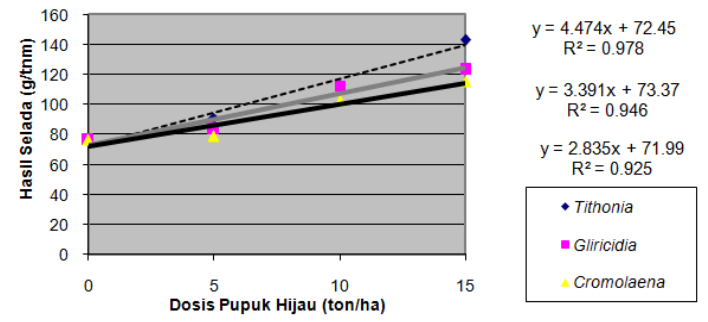

Gambar 3. Hubungan BS dengan dosis pupuk hijau

Perlakuan $\mathrm{OT}_{3}$ memberikan nilai bobot kering tertinggi pada umur $5 \mathrm{MSPT}$, namun tidak berbeda nyata dengan $\mathrm{OT}_{2}, \mathrm{OG}_{3}$ dan $\mathrm{OC}_{3}$ pada umur 4 MSPT. Peningkatan indek luas daun pada perlakuan penambahan pupuk hijau merupakan respon tanaman karena adanya kecukupan kebutuhan hidup sehingga tanaman mampu membentuk organ tubuh lebih banyak, termasuk organ fotosintesis. Indek luas daun yang tinggi menjadikan tanaman mempunyai kemampuan yang lebih tinggi dalam penangkapan cahaya matahari, dan mempunyai jumlah klorofil yang lebih banyak sehingga mampu melakukan kegiatan fotosintesis lebih tinggi, hasil selanjutnya adalah jumlah fotosintat tinggi, digunakan untuk membentuk dan mengisi jaringan tanaman sehingga tanaman selada mempunyai berat segar dan berat kering yang lebih tinggi. Sumbangan relatif keempat komponen cahaya; irradiasi langsung, radiasi difusi, refleksi dan transmisi tergantung pada jumlah dan tipe daun di dalam kanopi [6]. Jumlah tersebut biasanya dinyatakan sebagai indeks luas daun (ILD), yaitu suatu parameter tanpa satuan yang menunjukkan luas permukaan daun yang menutupi satu satuan luas tanah.

\section{Laju Pertumbuhan Tanaman}

Perlakuan memberikan pengaruh nyata pada laju pertumbuhan tanaman dalam selang 3-4 MSPT dan 4-5 MSPT. Kombinasi perlakuan Tithonia dengan dosis 15 ton.ha ${ }^{-1} \quad\left(\mathrm{OT}_{3}\right)$ menghasilkan nilai tertinggi laju pertumbuhan tanaman dalam selang 4-5 MSPT, sedangkan pada selang 3-4 MSPT $\mathrm{OT}_{3}$ tidak berbeda nyata dengan perlakuan lainnya kecuali dengan $\mathrm{OC}_{1}$ (Cromolaena dengan dosis 5 ton.ha ${ }^{-1}$ ). Rata-rata laju pertumbuhan tanaman pada selang 4-5 MSPT ditunjukkan pada Gambar 5.

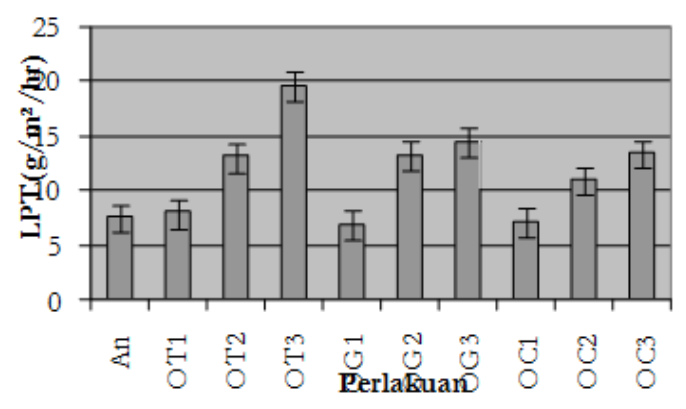

Gambar 4. Laju pertumbuhan tanaman selada pada 4-5 MSPT

Pembandingan kontras antara kontrol dengan penambahan pupuk hijau menunjukkan adanya perbedaan yang sangat nyata terhadap laju pertumbuhan tanaman. Peningkatan laju pertumbuhan tanaman akibat penambahan pupuk hijau sebesar sebesar $0,379 \mathrm{~g} \cdot \mathrm{m}^{-2} \cdot$ hari $^{-1}$ dan 1,814 g. $\mathrm{m}^{-2}$.hari ${ }^{-1}$ pada selang umur 2-3 MST dan 3-4 MST. 


\section{Laju Asimilasi Bersih}

Perlakuan memberikan pengaruh nyata terhadap laju asimilasi bersih pada selang 3-4 MSPT dan 4-5 MSPT. Perbandingan laju asimilasi bersih pada selang 4-5 MSPT ditunjukkan pada Tabel 1.

Tabel 1. Hasil pembandingan rata-rata laju asimilasi bersih umur 4-5 MSPT

\begin{tabular}{ccc}
\hline No & Perlakuan & $\begin{array}{c}\text { Laju Asimilasi Bersih } \\
\left(\mathbf{g} \cdot \mathbf{m}^{-\mathbf{2}} \cdot \mathbf{h}^{-\mathbf{1}} \mathbf{)}\right.\end{array}$ \\
\hline 1 & $\mathrm{An}$ & $7,110^{\mathrm{ab}}$ \\
2 & $\mathrm{OT}_{1}$ & $5,553^{\mathrm{a}}$ \\
3 & $\mathrm{OT}_{2}$ & $7,441^{\mathrm{ab}}$ \\
4 & $\mathrm{OT}_{3}$ & $8,503^{\mathrm{b}}$ \\
5 & $\mathrm{OG}_{1}$ & $5,536^{\mathrm{a}}$ \\
6 & $\mathrm{OG}_{2}$ & $8,095^{\mathrm{b}}$ \\
7 & $\mathrm{OG}_{3}$ & $7,482^{\mathrm{ab}}$ \\
8 & $\mathrm{OC}_{1}$ & $6,697^{\mathrm{ab}}$ \\
9 & $\mathrm{OC}_{2}$ & $7,399^{\mathrm{ab}}$ \\
10 & $\mathrm{OC}_{3}$ & $7,524^{\mathrm{ab}}$ \\
\hline
\end{tabular}

Keterangan :

Angka yang didampingi huruf berbeda pada kolom yang sama menunjukkan adanya perbedaan diantara perlakuan pada uji Tukey dengan taraf $\alpha=0,05$.

Nilai laju pertumbuhan tanaman dan indeks luas daun semakin tinggi sebagai akibat semakin besar dosis dan semakin baik kualitas pupuk hijau yang dipergunakan. Hal ini sesuai dengan hasil analisa komponen utama pada komponen utama 1 yang menunjukkan bahwa ILD, BK5 dan LPT tanaman memberikan sumbangan yang relatif sama yaitu: $0.546,0,537$, dan 0.536 terhadap pertumbuhan dan hasil tanaman selada. Semakin baik kualitas pupuk hijau maka semakin cepat proses dekomposisi dan mineralisasi sehingga mampu melepas unsur hara lebih cepat, maka kondisi ini mendukung pemenuhan kebutuhan unsur hara tanaman selada sejak awal yaitu sejak pindah tanam. Hal ini menunjukkan bahwa pupuk hijau dengan kualitas tinggi yang dipadukan dengan dosis 15 ton.ha ${ }^{-1}$ mampu mencapai sinkronisasi antara ketersediaan unsur hara oleh media tanam bersamaan dengan kebutuhan unsur hara oleh tanaman selada. Hal ini dibuktikan dari pencapaian nilai tertinggi pada saat panen oleh kombinasi perlakuan antara Tithonia dengan dosis 15 ton.ha ${ }^{-1}$ terhadap nilai berat segar, berat kering, luas daun, indek luas daun dan laju pertumbuhan tanaman.

Laju asimilasi bersih mempunyai pola yang berbeda dengan laju pertumbuhan tanaman. Laju asimilasi bersih merupakan jumlah total $\mathrm{CO}_{2}$ yang diambil tanaman dalam peristiwa fotosintesis dikurangi dengan $\mathrm{CO}_{2}$ yang hilang melalui respirasi jadi tidak semata-mata dihitung berda- sarkan kemampuan daun untuk menghasilkan bahan kering persatuan waktu, sehingga semakin tinggi luas daun belum tentu mampu menghasilkan berat kering tanaman yang tinggi persatuan luas daun yang ada [7].

Hasil penelitian menunjukkan bahwa perlakuan yang mampu memberikan nilai luas daun tinggi tidak diikuti dengan nilai laju asimilasi bersih yang tinggi. Pertumbuhan tanaman budidaya dengan meningkatnya indek luas daun, makin banyak daun yang terlindung, menyebabkan penurunan laju asimilasi bersih sepanjang musim pertumbuhan [8]. Pada tajuk dengan indek luas daun tinggi, daun muda pada puncak tanaman menyerap radiasi paling banyak, memiliki laju asimilasi bersih ke bagian tumbuhan yang lain. Sebaliknya, daun-daun yang lebih tua pada dasar tajuk dan terlindung mempunyai laju asimilasi $\mathrm{CO}_{2}$ yang rendah dan memberikan lebih sedikit hasil asimilasi kepada bagian tumbuhan yang lain.

Perlakuan yang mampu meningkatkan luas daun akan semakin meningkatkan nilai laju pertumbuhan tanaman, karena laju pertumbuhan tanaman dihitung berdasarkan luas tanah yang ditumbuhi tanaman tersebut (jarak tanamnya) sehingga faktor pembagi mempunyai nilai tetap, pada hal disisi lain nilai berat kering tanaman semakin naik dengan semakin tingginya luas daun. Namun laju asimilasi bersih pada perlakuan yang mampunyai nilai luas daun tinggi akan mampu menghasilkan berat kering tanaman total lebih tinggi. Hal ini dikarenakan berat kering total merupakan hasil kemampuan luas daun total dikalikan dengan kemampuan persatuan luas daun dalam laju asimilasi bersih.

\section{Hasil Tanaman}

Bobot segar dan kering tanaman selada pada saat panen dipengaruhi secara nyata oleh perlakuan. Perlakuan $\mathrm{OT}_{3}$ (Tithonia dosis 15 ton.ha ${ }^{-1}$ ) memberikan hasil tertinggi pada bobot segar dan kering pada saat panen (Gambar 5).

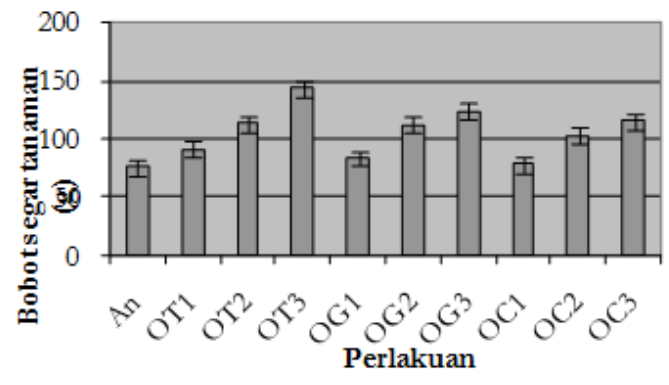

Gambar 5. Bobot segar tanaman saat panen 
Pembandingan kontras antara kontrol dengan pemberian pupuk hijau menunjukkan bahwa penambahan pupuk hijau 5 ton.ha $^{-1}$ dapat meningkatkan bobot segar dan bobot kering secara nyata pada saat panen yaitu sebesar 8,210 g dan 0,974 g. Hasil analisis komponen utama menunjukkan bahwa variabel pengamatan mempunyai sumbangan yang relatif sama yaitu ILD $=0,546$, BK5 =0,537, dan LPT $=0,536$, sedangkan laju asimilasi bersih memberikan pengaruh lebih rendah dan berbanding terbalik dengan variabel pertumbuhan lainnya, yaitu sebesar -0.354 (Tabel 2). Hal ini menunjukkan bahwa variabel pertumbuhan tersebut mempunyai peran yang sama dalam mendukung pertumbuhan dan hasil tanaman selada. Namun nilai laju asimilasi bersih lebih rendah sumbangannya terhadap hasil tanaman, karena nilai ini masih harus dikalikan dengan luas daun total tanaman untuk mendapatkan berat kering total tanaman.

Tabel 2. Analisis Komponen Utama

\begin{tabular}{ccccc}
\hline Proportion & 0.827 & 0.171 & 0.003 & 0.000 \\
\hline Cumulative & 0.827 & 0.997 & 1.000 & 1.000 \\
\hline Variable & PC1 & PC2 & PC3 & PC4 \\
\hline ILD & 0,546 & $-0,092$ & 0,830 & 0,061 \\
LPT & 0,536 & $-0,264$ & $-0,328$ & $-0,731$ \\
LAB & $-0,354$ & $-0,926$ & 0,129 & 0,017 \\
BK5 & 0,537 & $-0,253$ & $-0,431$ & 0,679 \\
\hline
\end{tabular}

Luas daun dan indek luas daun memberikan sumbangan lebih besar dibandingkan dengan variabel lainnya. Hal ini menunjukkan bahwa kemampuan pertumbuhan dan hasil tanaman didasarkan oleh kemampuan daun untuk berfotosintesis, sehingga daun yang lebih luas akan mampu menghasilkan fotosintat yang lebih tinggi. Sebagai buktinya adalah pada perlakuan yang memberikan nilai luas daun dan indek luas daun tinggi mampu menghasilkan berat kering dan berat segar panen yang tinggi pula. Suatu ukuran yang dapat membantu menentukan infestasi produktif tanaman yaitu suatu ukuran yang sangat penting dalam proses pertumbuhan tanaman yaitu daun [7]. Daun merupakan produksen fotosintat paling penting dalam tanaman secara umum, dan intersepsi cahaya dan fotosintesa tergantung sebagian besar pada luas daun.

\section{Kesuburan Tanah}

Pemberian pupuk hijau dengan dosis 15 ton.ha ${ }^{-1}$ mampu meningkatkan bahan organik tanah, $\mathrm{N}$ total tanah, dan KTK pada saat setelah panen dari kondisi awal sebelum penanaman, maupun terhadap kontrol pada saat yang sama. Pupuk hijau yang kualitasnya lebih rendah memberikan sumbangan yang lebih besar terhadap kandungan bahan organik tanah, N total tanah, KTK, dan penurunan bobot isi tanah pada saat setelah panen.

Perlakuan memberikan pengaruh yang nyata terhadap $\mathrm{C}$ organik tanah pada saat setelah panen. $\mathrm{OC}_{3}$ (Cromolaena dosis 15 ton.ha ${ }^{-1}$ ) memberikan sumbangan $C$ organik tanah paling tinggi dibandingkan dengan semua kombinasi perlakuan yang diujikan. Pengaruh masingmasing kombinasi perlakuan terhadap $\mathrm{C}$ organik tanah ditunjukkan pada Tabel 3.

Tabel 3. Hasil pembandingan rata-rata $C$ organik tanah akibat perlakuan pada saat setelah panen

\begin{tabular}{cccc}
\hline No. & Perlakuan & C organik tanah (\%) \\
\hline 1 & $\mathrm{An}$ & $1,460 \mathrm{a}$ \\
2 & $\mathrm{OT}_{1}$ & $1,500 \mathrm{a}$ \\
3 & $\mathrm{OT}_{2}$ & $1,620 \mathrm{~b}$ \\
4 & $\mathrm{OT}_{3}$ & $2,030 \mathrm{de}$ \\
5 & $\mathrm{OG}_{1}$ & $1,520 \mathrm{a}$ \\
6 & $\mathrm{OG}_{2}$ & $1,720 \mathrm{c}$ \\
7 & $\mathrm{OG}_{3}$ & $2,103 \mathrm{e}$ \\
8 & $\mathrm{OC}_{1}$ & $1,740 \mathrm{c}$ \\
9 & $\mathrm{OC}_{2}$ & $1,970 \mathrm{~d}$ \\
10 & $\mathrm{OC}_{3}$ & $2,230 \mathrm{f}$ \\
\hline
\end{tabular}

Keterangan :

Angka yang didampingi huruf berbeda pada kolom yang sama menunjukkan adanya perbedaan diantara perlakuan pada uji Tukeys dengan taraf $\alpha=0,05$.

Perlakuan memberikan pengaruh yang nyata terhadap KTK tanah pada saat setelah panen. Perlakuan $\mathrm{OC}_{3}$ (Cromolaena dengan dosis 15 ton. ha $^{-1}$ ) memberikan nilai KTK tanah tertinggi. Pembandingan rata-rata KTK tanah akibat perlakuan ditunjukkan pada Tabel 4.

Bahan organik merupakan penyangga biologi yang mempunyai fungsi dalam memperbaiki sifat-sifat fisik, kimia dan biologi tanah, sehingga tanah dapat menyediakan unsur hara dalam jumlah berimbang. Terdapat korelasi positif antara kadar bahan organik dengan produktifitas tanah. Bahan organik juga berfungsi sebagai sumber bahan energi bagi mikrobia [2].

Bahan organik merupakan salah satu komponen tanah yang sangat penting bagi ekosistem tanah, dimana bahan organik merupakan sumber dan pengikat hara dan sebagai substrat bagi mikroba tanah [9]. Mineralisasi bahan organik dapat meningkatkan 
ketersediaan hara tanah dan nilai kapasitas tukar kation tanah, sehingga kehilangan hara melalui proses pencucian dapat dikurangi.

Tabel 4. Hasil pembandingan rata-rata KTK tanah akibat perlakuan pada saat setelah panen

\begin{tabular}{ccc}
\hline No. & Perlakuan & KTK tanah $\left(\mathbf{m e . 1 0 0}^{-\mathbf{1}}\right)$ \\
\hline 1 & $\mathrm{An}$ & $29,84 \mathrm{a}$ \\
2 & $\mathrm{OT}_{1}$ & $30,64 \mathrm{~b}$ \\
3 & $\mathrm{OT}_{2}$ & $31,25 \mathrm{c}$ \\
4 & $\mathrm{OT}_{3}$ & $32,85 \mathrm{de}$ \\
5 & $\mathrm{OG}_{1}$ & $30,46 \mathrm{~b}$ \\
6 & $\mathrm{OG}_{2}$ & $32,64 \mathrm{~d}$ \\
7 & $\mathrm{OG}_{3}$ & $33,23 \mathrm{e}$ \\
8 & $\mathrm{OC}_{1}$ & $30,72 \mathrm{~b}$ \\
9 & $\mathrm{OC}_{2}$ & $33,10 \mathrm{de}$ \\
10 & $\mathrm{OC}_{3}$ & $34,24 \mathrm{f}$ \\
\hline
\end{tabular}

Keterangan :

Angka yang didampingi huruf berbeda pada kolom yang sama menunjukkan adanya perbedaan diantara perlakuan pada uji Tukeys dengan taraf $\alpha=0,05$

Cromolaena odorata dengan kandungan C organik tinggi menyebabkan paling lambat dalam dekomposisi, sehingga memberikan sumbangan C organik tanah lebih tinggi daripada Tithonia dan Gliricidia. Kecepatan dekomposisi bahan organik berkorelasi sangat nyata dengan kandungan $\mathrm{C}$ organik namun tidak berkorelasi nyata dengan parameter kualitas bahan organik lainnya [10]. Hal ini menunjukkan bahwa peningkatan $\mathrm{C}$ organik pada bahan organik akan menurunkan kecepatan dekomposisi. Bahan organik dengan kandungan $\mathrm{C}$ organik yang tinggi menunjukkan banyaknya fraksi tahan lapuk dalam pangkasan.

Tithonia dan Gliricidia memberikan sumbangan $\mathrm{C}$ organik kedalam tanah lebih kecil. Biomasa bahan organik dengan kualitas tinggi akan cepat habis terdekomposisi dan sedikit meningkatkan bahan organik tanah dikarenakan sedikitnya bahan tahan lapuk dalam biomasa bahan organik [10].

Cromolaena odorata merupakan pupuk hijau yang dapat meningkatkan nilai KTK tertinggi dibandingkan perlakuan lainnya. Hal ini dikarenakan bahan organik ini merupakan bahan organik yang lambat terdekomposisi sehingga dapat meningkatkan kandungan bahan organik tanah yang pada giliran berikutnya akan meningkatkan KTK. Faktor yang mempengaruhi peningkatan KTK selain jenis dan jumlah liat adalah kandungan bahan organik tanah [11].

Perlakuan pemberian biomasa bahan organik akan meningkatkan koloid organik tanah yang terdiri dari $\mathrm{C}, \mathrm{O}$ dan $\mathrm{H}$ yang memiliki daya jerap kation yang lebih tinggi dibandingkan liat. Peningkatan KTK menunjukkan peningkatan kemampuan tanah dalam mengikat dan menyediakan unsur hara yang lebih baik bagi tanaman. KTK tanah yang tinggi akan melindungi unsur hara dalam larutan tanah dari pencucian akibat perkolasi air. Unsur hara yang berada dalam kompleks jerapan koloid tidak mudah tercuci ke lapisan tanah yang lebih dalam [12]. Cromolaena odorata mampu menurunkan bobot isi tanah paling tinggi. Hal ini dikarenakan kandungan bahan tahan lapuk yang lebih tinggi sehingga bahan organik menjadi lebih lambat untuk didekomposisi, sehingga mempunyai waktu tinggal dalam tanah lebih lama.

\section{Pertumbuhan dan Hasil Tanaman Selada dengan Kesuburan Tanah}

Pertumbuhan dan hasil tanaman selada yang baik membutuhkan kondisi tanah yang baik secara biologi, kimia maupun fisiknya. Pemberian pupuk hijau dengan dosis dan jenis yang berbeda memberikan pengaruh yang berbeda terhadap kesuburan tanah. Hal ini dikarenakan setiap jenis pupuk hijau yang mempunyai kandungan $\mathrm{C}$ organik, $\mathrm{N}$ organik, $\mathrm{CN}$ ratio, lignin dan polifenol akan menentukan proses dekomposisi dan mineralisasi bahan organik tersebut yang pada giliran selanjutnya adalah peningkatan kandungan bahan organik tanah yang diidentifikasi dari $\mathrm{C}$ organik tanah. Peningkatan efisiensi pemanfaatan pupuk atau hara ditunjukkan dengan nilai KTK, reaksi tanah dengan $\mathrm{pH}$ tanah. Sumbangan hara $\mathrm{N}$ dengan identifikasi $\mathrm{N}$ total tanah dan kegemburan tanah dengan bobot isi tanah.

Pupuk hijau dapat memperbaiki sifat fisik dan kimia tanah, peningkatan $\mathrm{pH}$, peningkatan KTK, peningkatan serapan $\mathrm{P}$ dan menurunkan $\mathrm{AL}$ di tanah. Dengan pupuk hijau dapat meningkatkan kesuburan tanah dalam pola tanam dan dapat meningkatkan biomas dan produksi tanaman pangan [13]. Pupuk hijau dengan kualitas tinggi seperti Tithonia dan Gliricidia yang dipadukan dengan dosis 15 ton. ha ${ }^{-1}$ memberikan sumbangan hara $\mathrm{N}$, pertumbuhan dan hasil tanaman selada yang lebih tinggi dibandingkan dengan Cromolaena. Takaran pupuk hijau berpengaruh nyata terhadap pertumbuhan, berat pipilan kering dan berat basah jagung [14].

Perbedaan sumbangan hara $\mathrm{N}$, pertumbuhan dan hasil tanaman selada akibat perlakuan macam dan dosis pupuk hijau disebabkan adanya perbedaan kandungan $\mathrm{N}$ dan $\mathrm{C}$ organik pada 
pupuk hijau tersebut. Tithonia mengandung $\mathrm{N}$ sebesar 5,14\% dan C organik sebesar 34,45\%, Gliricidia mengandung $38,28 \%$ C dan $4,06 \% \mathrm{~N}$. Sedangkan Cromolaena mengandung 40,24\% C dan 3,8\% N. Sehingga Tithonia mengandung N tertinggi dan $\mathrm{C}$ organik terendah. Karakteristik ini menyebabkan Tithonia mempunyai proses dekomposisi lebih cepat. Kecepatan dekomposisi bahan organik berkorelasi sangat nyata dengan kandungan $\mathrm{C}$ organik namun tidak berkorelasi nyata dengan parameter kualitas bahan organik lainnya [10]. Hal ini menunjukkan bahwa peningkatan $\mathrm{C}$ organik pada bahan organik akan menurunkan kecepatan dekomposisi. Bahan organik dengan kandungan $\mathrm{C}$ organik yang tinggi menunjukkan banyaknya fraksi tahan lapuk dalam pangkasan.

Tithonia mempunyai kandungan $\mathrm{N}$ yang tinggi sehingga melepas $\mathrm{N}$ lebih tinggi ke dalam tanah. Sebagaimana ditunjukan oleh hasil analisa tanah 3 MSPT yang menunjukkan kandungan $\mathrm{N}$ total tanah lebih rendah akibat pemupukan Tithonia dan Gliricidia. Namun kandungan $\mathrm{NH}_{4}$ dan $\mathrm{NO}_{3}$ lebih tinggi dibandingkan Cromolaena. Tingginya kandungan $\mathrm{NH}_{4}$ dan $\mathrm{NO}_{3}$ pada saat $3 \mathrm{MSPT}$ disebabkan adanya pemupukan Urea pada saat tanaman berumur 1 MSPT. Keberadaan bahan organik yang meningkatkan KTK sehingga $\mathrm{NH}_{4}$ dan $\mathrm{NO}_{3}$ tidak mudah hilang karena pencucian. Kandungan $\mathrm{N}$ tanah setelah panen akibat pemupukan Tithonia lebih rendah dibandingkan dengan Gliricidia dan Cromolaena. Namun $\mathrm{N}$ total yang ditemukan dalam jaringan tanaman selada akibat perlakuan Tithonia lebih tinggi apabila dibandingkan dengan pupuk hijau yang lain. Hal ini menunjukkan bahwa kecepatan pelepasan dan jumlah $\mathrm{N}$ oleh Tithonia lebih sinkron dengan kebutuhan tanaman selada.

Laju mineralisasi nitrogen juga dikendalikan oleh kandungan $\mathrm{N}$ total tanah, lamanya inkubasi dan temperatur inkubasi [15]. Ketiga faktor ini memberikan pengaruh positif terhadap laju mineralisasi N. Selain itu, penambahan urea pada tanah akan mempercepat mineralisasi $N$ [15]. Perbedaan kandungan $\mathrm{C}$ organik tanah akan mengendalikan perbedaan tambahan kecepatan akibat penambahan urea ini.

Cromolaena menyumbang nilai yang lebih tinggi pada KTK, N total, C organik dan penurunan bobot isi tanah dibanding Tithonia dan Gliricidia pada saat setelah panen. Hal ini disebabkan Cromolaena mempunyai kecepatan dekomposisi lebih rendah sehingga bahan tahan lapuk pada bahan organik ini, lebih lama tinggal di dalam tanah yang selanjutnya akan menaikkan
C organik tanah, KTK, N total tanah dan menurunkan bobot isi tanah. $\mathrm{N}$ total tanah akibat penambahan Cromolaena ditemukan lebih tinggi pada saat setelah panen, karena pelepasan $\mathrm{N}$ oleh bahan organik ini lebih lama. Sehinggga pada saat akhir panen pelepasan $\mathrm{N}$ akumulasinya tinggi. Sedangkan pupuk hijau yang lain, $\mathrm{N}$ yang dilepaskan sudah dimanfaatkan oleh tanaman atau hilang. Hal ini serupa dengan penelitian sebelumnya yang menyatakan bahwa pemberian bahan organik pada lahan kering berupa kompos dan sisa-sisa tanaman dalam tiga tahun memperbaiki sifat tanah $[16,17]$ yaitu menurunkan kepadatan tanah, memantapkan agregat tanah, menurunkan kecepatan perkolasi, dan meningkatkan kapasitas tukar kation (KTK) tanah.

\section{KESIMPULAN}

Penambahan pupuk hijau 5 ton.ha ${ }^{-1}$ pada budidaya selada yang dipupuk urea dapat meningkatkan indeks luas daun, bobot segar, bobot kering tanaman pada saat panen dan laju pertumbuhan tanaman. Hasil tertinggi dicapai pada penambahan Tithonia 15 ton.ha ${ }^{-1}$ yang meningkatkan hasil selada sebear 67,1 g per tanaman atau meningkat $88 \%$ dari pemupukan urea. Selain itu penambahan pupuk hijau 5 ton. $\mathrm{h}^{-1}$ pada bubidaya selada yang dipupuk urea dapat meningkatkan KTK tanah dan C organik tanah setelah panen. Hasil tertinggi dicapai pada Cromolaena 15 ton.ha ${ }^{-1}$ yang dapat meningkatkan KTK tanah sebesar 4,4 me. $100 \mathrm{~g}^{-1}$ atau meningkat $14,75 \%$ dan $C$ organik tanah sebesar $1,03 \%$ atau meningkat $53,1 \%$.

\section{DAFTAR PUSTAKA}

[1] Sugito, Y. 2000. Pembangunan pertanian berkelanjutan di Indonesia: prospek dan permasalahannya. Makalah Seminar Nasional Pembangunan Berkelanjutan. Malang.

[2] Prihatini, T., A. Kentjanasari, J. S. Adiningsih. 1996. Peningkatan kesuburan tanah melalui pemanfaatan Biofertilizer dan bahan organik. Makalah Seminar Nasional Pengelolaan Tanah Masam Secara Biologi. Universitas Brawijaya. Malang.

[3] Adiningsih, J. S., A. S. Karama. 1992. A sustainable upland farming system for Indonesia. Centre for Soil and Agroclimate Research (RSAR). Bogor. $12 \mathrm{p}$.

[4] Hairiah, K. 2000. Pengelolaan tanah masam secara biologi. ICRAF SE Asia. Bogor. 
[5] Hunt, R. 1978. Plant growth analysis. Studies in biology no.96. Edward Arnold. London. $67 \mathrm{p}$.

[6] Fitter, A. H., R. K. M. Hay. 1998. Fisiologi lingkungan tanaman. Andani, S., E. D. Purbayanti (TransI). Gadjah Mada University Press. Yogyakarta.

[7] Sitompul, S. M., B. Guritno. 1995. Analisis pertumbuhan tanaman. Gadjah Mada University Press. Yogyakarta.

[8] Gardner, F.P., R. B. Pearce, R. L. Mitchell. 1991. Fisiologi tanaman budidaya. Susilo, H. (Transl). Universitas Indonesia Press. Jakarta.

[9] Hairiah, K .1997. Dinamika C dalam tanah. Diktat Kuliah Kesuburan tanah. Pasca Sarjana Universitas Brawijaya. Malang.

[10] Pratikno, H. 2001. Studi pemanfaatan berbagai biomasa flora untuk peningkatan ketersediaan $\mathrm{P}$ dan bahan organik tanah berkapur di DAS Brantas Malang Selatan. Thesis. Universitas Brawijaya. Malang.

[11] Soepardi, G. 1983. Sifat dan ciri tanah. Fakultas Pertanian, Institut Pertanian Bogor. Bogor.

[12] Hardjowigeno, S. 1992. Ilmu tanah. Mediyatama Sarana Perkasa. Jakarta.

[13] Sastrosudarjo, S. 1984. Improvement of organic matter in upland farming systems. Proceeding Pertemuan Teknis Penelitian Pola Usaha Tani Menunjang Transmigrasi.

[14] Haryati, U., A. Rachman, A. Abdurachman. 1990. Aplikasi mulsa dan pupuk hijau Sonosiso untuk pertanaman jagung pada tanah Usthorthents di Gondanglegi. 1-8. dalam Risalah Pembahasan Hasil Penelitian Pertanian Lahan Kering dan Konservasi Tanah. Tugu-Bogor. Proyek Penelitian Penyelamatan Hutan, Tanah dan Air (P3HTA), Salatiga, Departemen Pertanian.

[15] Poerwowidodo, 1992. Telaah kesuburan tanah 4 Ed. Penerbit Angkasa Persada. Bandung.

[16] Karama, A. S., A.R. Marzuki, I. Manwan. 1994. Penggunaan pupuk organik pada tanaman pangan. Balai Penelitian Tanaman Pangan. Bogor.

[17] Handayanto, E., G. Cadisch, K.E. Giller. 1994. Nitrogen release from prunings of Legume Hedgerow Trees in relation to quality of the prunings and incubation method. Plant and Soil. 1660. $237-248$. 